\title{
Diabetes Health Promotion Self-Care Scale: Reliability and Validity of the Turkish Version
}

\author{
Diyabet Sağhl̆̆ın Geliştirme Öz Bakım Ölçeği: Türkçe Formunun Güvenirlik ve Geçerliliği
}

\section{${ }^{1}$ Ayfer Peker Karatoprak, ${ }^{1}$ Selda Mert, ${ }^{2}$ Yeliz Demirhan, ${ }^{3}$ Insaf Altun, ${ }^{4}$ Canan Baydemir, ${ }^{5}$ Mehmet Sozen, \author{
${ }^{1}$ Levent Aydin, ${ }^{5}$ Berrin Cetinarslan, ${ }^{5}$ Zeynep Canturk, ${ }^{5}$ Alev Selek \\ (i1)
}

${ }^{1}$ Kocaeli University, Kocaeli Vocational School of Health Services, Kocaeli, Turkey

${ }^{2}$ Kocaeli University Research and

Application Hospital, Diabetes Policlinic,

Kocaeli, Turkey

${ }^{3}$ Faculty of Health Sciences, Department of Fundamentals in Nursing, İstinye

University, Cevizlibag, Istanbul, Turkey.

${ }^{4}$ Kocaeli University Faculty of Medicine, Department of Biostatistics and Medical Informatics,

Kocaeli, Turkey

${ }^{5}$ Kocaeli University Faculty of

Medicine, Department of Endocrinology and Metabolic Diseases, Kocaeli, Turkey
Correspondence:

Mehmet SÖZEN

Kocaeli University Faculty of

Medicine, Department of

Endocrinology and Metabolic

Diseases,

Kocaeli, Turkey

e-mail:mehmetsozen07@gmail.com

\section{Abstract}

This study was carried out to put the Diabetes Health Promotion Self-Care Scale for patients with Type 2 diabetes mellitus (DM) into use for nursing and medical literature. The sample of this methodological design research consisted of 620 patients diagnosed with type 2 DM. The data were collected with Personal Information Form and the Diabetes Health Promotion Self-Care Scale. In the validity and reliability stage of the scale, exploratory and confirmatory factor analyzes, and structural equation modeling was used for the item analyzes, internal consistency, and structural validity. The statistical analysis showed that the reliability coefficient of the scale was Cronbach $\alpha=0.922$. The sub-factors of the Diabetes Health Promotion Self-Care Scale consisting of 27 items and 7 sub-factors were determined as "Interpersonal Relationships", "Blood glucose self-monitoring", "Personal Health Responsibility", "Exercise", "Diet", "Adherence to the Recommended Regime", and "Foot Care". As a result of the analysis, the Diabetes Health Promotion Self-Care Scale was found as a valid and reliable scale to be applied to Turkish society.

Keywords: Diabetes health promotion self-care, instrument development, reliability, validity, type 2 diabetes mellitus

\section{Özet}

Bu çalışma, Tip 2 diabetes mellitus (DM) hastalarına yönelik Diyabet Sağlığı Geliştirme Öz Bakım Ölçeği’nin hemşirelik ve tıp literatürüne kazandırılması amacıyla yapılmıștır. Bu metodolojik tasarım araștırmasının örneklemini tip 2 DM tanısı almıs 620 hasta oluşturmuştur. Veriler Kişisel Bilgi Formu ve Diyabet Sağlığı Geliştirme Öz Bakım Ölçeği ile toplanmıştır. Ölçeğin geçerlik ve güvenirlik aşamasında, madde analizleri, iç tutarlılık ve yapı geçerliliği için açımlayıcı ve doğrulayıcı faktör analizleri ile yapısal esitlik modellemesi kullanılmıștır. İstatistiksel analiz, ölçeğin güvenirlik katsayısının Cronbach $\alpha=0,922$ olduğunu göstermiștir. 27 madde ve 7 alt faktörden oluşan Diyabet Sağllğı Geliştirme Öz Bakım Ölçeği’nin alt faktörleri şu şekilde belirlenmiştir: "Kişilerarası İlişkiler", "Kan şekeri kendini izleme”, "Kişisel Sağlık Sorumluluğu”, "Egzersiz”, "Diyet" olarak belirlenmiştir. ", "Önerilen Rejime Uyum” ve "Ayak Bakımı”. Analiz sonucunda Diyabet Sağlığı Geliștirme Öz Bakım Ölçeği’nin Türk toplumu için geçerli ve güvenilir bir ölçek olduğu görülmüştür.

Anahtar Kelimeler: Diyabette sağlığın teşviki ve geliştirilmesi özbakım, araç geliştirme, güvenilirlik, geçerlik, tip 2 diabetes mellitus 


\section{Introduction}

Diabetes Mellitus (DM) is a serious metabolic disease due to its prevalence and complications (1). DM affects $25 \%$ of the world population, and approximately $90 \%$ of all diabetic patients are type 2 , and $10 \%$ are type 1 diabetes patients (2). According to the studies carried out by the Turkish Diabetes Epidemiology project group between 1997 and 1998 , diabetes prevalence was $7.2 \%$, and prevalence of prediabetes was $6.7 \%$ in our country (3).

Diabetes causes high health costs and complications that affect people in many ways. Individuals' compliance and self-care behaviors constitute $98 \%$ of diabetes care for the prevention of complications and diabetes treatment (4). Even though the importance of these behaviors is well-understood by both patients and health professionals, successful implementation of these behaviors is generally not achieved $(5,6)$. Self-efficacy is regarded as the most significant indicator of self-care in between type 2 DM cases. (7).

Self-care is defined to actions which people take for their care within their environmental conditions by Orem (8). Although the term health promotion is not defined in Orem's Self Care Deficit Theory, it is considered as the outcomes achieved through self-care. Protection and promotion of health is an indispensable part of nursing care. Nursing practices, education, and research should clarify the activities for health promotion and ensure their applicability (9).

People with diabetes who encounter complex and challenging activities due to diabetes control generally experience emotional problems, and their quality-of-life decreases (10). Therefore, in diabetes management, in addition to physical issues, psychosocial issues should also be considered $(11,12)$. Health promotion focuses on improving physical and psychosocial well-being. Implementing health-promoting behaviors is a significant strategy for the maintenance and improvement of the quality of life in people who have chronic disabilities (13).

Various instruments have been created to evaluates self-care behaviors that strengthen the health of people with diabetes like the Summary of Diabetes Self-Care Measures (SDSCA) and Self-Care Inventory-Revised (SCI-R) form (14). The recently revised 11item SDSCA evaluates diet, blood glucose testing, foot care, and smoking behavior (15). SCI-R, on the other hand, is a 14-subject scale which measure people' perceptions of compliance with therapeutics recipes (16). Both SDSCA and SCI-R measure disease control self-care behavior but overlook the measurement of psychosocial health-related self-care behavior. Diabetes Self-Care Scale (DSCS) is another scale that was developed in the USA and adapted to Turkish culture as the Diabetes Self-Care Scale (DSCS) (17). The scale consists of 35 items, including information about diabetes and its complications but ignores the psychosocial situation. The Diabetes Management SelfEfficacy Scale (DHPSC) is recommended as the most appropriate tool for eventual usege in practice and research. The quantification equability over languages, measurement mistake, and responsiveness of this tool is suggested to be evaluated (18). DHPSC, created by Wang et al. for type 2 diabetes mellitus patients, consists of sub-items that question physical activity, nutrition, selfmonitoring of blood glucose, adherence to regimens, foot care, personal health responsibility, and interpersonal relationships. The scale is reported to be supplementary in promoting the DM patient's physical and psychosocial health (19).

Health-promoting behavior is a multidimensional model of self-induced activitiess and sensationss that which to resume or improve health. Despite different reinforcement approaches and modern monitoring devices, many people still have challenges with self-management of diabetes (20). Moreover, individual health responsibleness is a major condition to strengthening of DM people (21). Our study aimed to form, examine, and adapt the psychometric resources of the DHPSC developed for individuals with DM. 


\section{Material and Methods}

\section{Research design and sample}

The study was performed within a methodological model to improve and test the psychometric properties of the DHPSC developed by Wang et al. (19) for individuals with Type $2 \mathrm{DM}$ and adapt it to the Turkish language.

The population was composed of adult type 2 diabetes patients admitted to a university hospital diabetes polyclinic in Kocaeli between May 2021 and July 2021. The entire population was tried to be reached without performing a sample selection. The data of the study were obtained from voluntary patients with type 2 diabetes on the specified dates.

When adopting a scale to another culture, the case extent for a definitive factor analysis should be at least 5 to 10 times bigger than the number of scale units (22). Based on this suggestion, 620 individuals with Type $2 \mathrm{DM}$ volunteering to take part in our academic work and acknowledged to the survey were inclusived in the study. The response rate was $65.2 \%$. The patients fitting the inclusion criteria were chosen by using a random sampling method. We adopted DHPSC to Turkish culture in three phases: (a) language validity, (b) scale validity, and (c) scale reliability.

The DHPSC has seven behavior dimensions: diet, exercise, blood glucose self-monitoring, adherence to recommended regimens, foot care, interpersonal relationships, and personal health responsibility.

\section{Data collection}

The data were collected between May 2021 and July 2021 after obtaining written and verbal consent from volunteer participants with diabetes by filling out the forms together. It took about 5-7 minutes to proper all the data collection form. The Personal Information Form and the DHPSC were used for data collection.

\section{Instruments}

The personal information form: It includes 4 socio-demographic questions as age, gender, marital status, educational status, and 3 questions regarding essences of the illness, including duration of diabetes, treatment method in diabetes, and body mass index.

Diabetes Health Promotion Self-Care Scale: DHPSC was improved by Wang et al. in 2012 and includes 7 parts as diet (three items), exercise (three items), blood glucose selfmonitoring (five items), adherence to the recommended regime (three items), foot care (two items), interpersonal relationships (seven items) and personal health responsibility (five items). The DHPSC scale is a 28 -item scale with seven behavioral dimensions. The scale has a 5-point assessment, ranging from 'always' (5 points) to 'never' (1 point). High scores indicate that health care behaviors were better. The Cronbach alpha reliability coefficients of the scale and its sub-factors were found to be $\alpha=0.922$, and $\alpha=0.689$ 0.925 , respectively (Table 1 ).

Table 1. Correlations and Cronbach $\alpha$ values for the Sub-Factors of the DHPSC

\begin{tabular}{|c|c|c|c|c|c|c|c|c|c|}
\hline$r(p)^{*}$ & & $\begin{array}{l}\text { Interpersonal } \\
\text { Relationship } \\
\text { s (Factor 1) }\end{array}$ & $\begin{array}{l}\text { Blood Glucose } \\
\text { Self-Monitoring } \\
\text { (Factor 2) }\end{array}$ & $\begin{array}{c}\text { Personal } \\
\text { Health } \\
\text { Responsibili } \\
\text { ty (Factor } \\
\text { 3) }\end{array}$ & $\begin{array}{l}\text { Exercise } \\
\text { (Factor } \\
\text { 4) }\end{array}$ & $\begin{array}{c}\text { Diet } \\
\text { (Factor } \\
\text { 5) }\end{array}$ & $\begin{array}{l}\text { Adherence to } \\
\text { the } \\
\text { Recommended } \\
\text { Regimens } \\
\text { (Factor 6) }\end{array}$ & $\begin{array}{c}\text { Foot } \\
\text { Care } \\
\text { (Factor } \\
7) \\
\end{array}$ & $\begin{array}{c}\text { Cronbac } \\
\text { h } \alpha\end{array}$ \\
\hline \multirow[b]{2}{*}{ Factor 1} & $\mathrm{r}$ & \multirow[b]{2}{*}{ - } & 0.264 & 0.371 & 0.208 & 0.242 & 0.266 & 0.325 & \multirow[b]{2}{*}{0.896} \\
\hline & $\mathrm{p}$ & & $<0.001$ & $<0.001$ & $<0.001$ & $<0.001$ & $<0.001$ & $<0.001$ & \\
\hline \multirow[t]{2}{*}{ Factor 2} & $\mathrm{r}$ & & - & 0.579 & 0.359 & 0.548 & 0.374 & 0.375 & \multirow{2}{*}{0.831} \\
\hline & $\mathrm{p}$ & & & $<0.001$ & $<0.001$ & $<0.001$ & $<0.001$ & $<0.001$ & \\
\hline \multirow{2}{*}{ Factor 3} & $\mathrm{r}$ & & & - & 0.298 & 0.514 & 0.374 & 0.415 & \multirow[t]{2}{*}{0.856} \\
\hline & $\mathrm{p}$ & & & & $<0.001$ & $<0.001$ & $<0.001$ & $<0.001$ & \\
\hline Factor 4 & $\mathrm{r}$ & & & & - & 0.465 & 0.122 & 0.332 & 0.925 \\
\hline
\end{tabular}




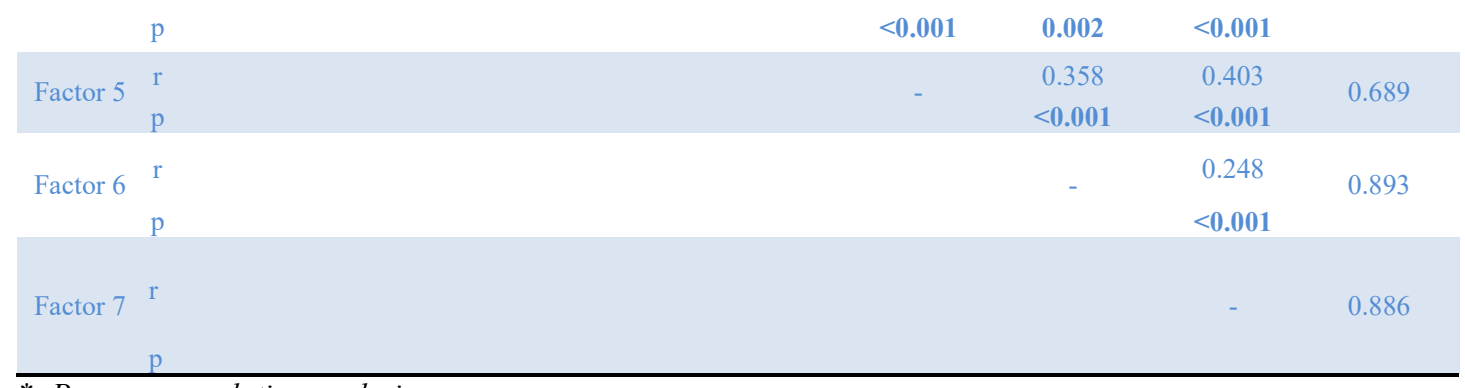

*: Pearson correlation analysis

\section{Subfactors of the scale}

Factor 1- Interpersonal Relationships: The interpersonal relationships section consists of 7 items that show positive communication and sharing with the family and the people around you.

Factor 2 - Blood Glucose Self-Monitoring: There are 5 items in this section that examine the adaptation of knowledge, attitudes, and behaviors regarding the measurement of blood glucose and urinary glucose levels to social life and preventing hypoglycemia during exercise.

Factor 3 - Personal Health Responsibility: Personal health responsibility sub-factor includes 5 items as attitudes and behaviors in situations that require consultation, interest in training programs, and blood glucose monitoring.

Factor 4 - Exercise: The exercise section has 3 items that question compliance with the exercise program.

Factor 5 - Diet: It consists of 3 items, including knowledge, attitudes, and behaviors related to diet.

Factor 6 - Adherence to the Recommended Regimens: In this section, two items question the correct use of the prescribed drugs.

Factor 7 - Foot Care: This section consists of 2 items as foot care practices and shoe/socks selection.

Based on these seven factors, items loaded on each factor were added as individual scores of diabetics and sub-factors were created.

\section{Language validity}

In the first phase, three independent translators who can speak English translated the scale into Turkish. Then, the researchers examined the translations and formed a single version. In the next step, the translation of the scale back to English was done by three expert trainers in the concerned area and are competent in both languages fine. The first shape of the scale and its back translation were compared and each of unit were analysed. Finally, the Turkish version of the scale was finished since there was no gap in the accessibility of the scale items.

\section{Analysis}

Statistical evaluation was done with IBM SPSS 20.0 (IBM Corp., Armonk, NY, USA) and Linear Structural Relationships package programs (LISREL v8.8, Inc. SSI. Lincoln, IL, USA). The compliance of numerical variables to normal distribution was evaluated with the Kolmogorov-Smirnov Test. Numerical variables were given as median (25.-75.) and frequency (percentages). To evaluate the language comprehensibility of the scale questions, it was first translated into Turkish, and then back to English, which was the original language, and sent to the expert who developed the scale to get an opinion. For the clearness of the questions, the Pearson correlation coefficient was calculated for testretest reliability performed at two-week intervals. For the internal consistency of the DHPSC and sub-factors, Cronbach $\alpha$ coefficient was calculated separately. Exploratory Factor Analysis was conducted to test the validity of the scale's structure in Turkish culture. To determine the factors and, appropriate factors, the principal components analysis method and the Varimax factor rotation method were performed, respectively. The suitability of the sample was tested with the Kaiser-Meyer-Olkin coefficient. The Bartlett's Sphericity Test was used for the suitability of the data for factor analysis. The criteria to retain all the factors with 
Eigenvalues greater than 1 (Kaiser Criterion) was used. The compatibility of the sub-factors with the original variables was measured using Confirmatory Factor Analysis. To check the newly created constructive model, the Structural Equation Modeling (SEM) method was used. The relationship between the subfactors of the DHPSC's was calculated by Pearson's correlation coefficient. $\mathrm{p}<0.05$ was considered sufficient for statistical significance in two-way tests.

\section{Results}

\section{Sample characteristics}

The sociodemographic aspects of the patients are given in Table 2 .

Table 2. Disease-related characteristics and The DHPSCsub-factor and total score averages $(n=620)$

\begin{tabular}{|c|c|c|c|}
\hline Characteristics & $\mathrm{n}$ & \multicolumn{2}{|c|}{$\%$} \\
\hline \multicolumn{4}{|l|}{ Gender } \\
\hline Female & 412 & \multicolumn{2}{|c|}{66.5} \\
\hline Male & 208 & \multicolumn{2}{|c|}{33.5} \\
\hline \multicolumn{4}{|l|}{ Marital Status } \\
\hline Married & 486 & \multicolumn{2}{|c|}{78.4} \\
\hline Single & 134 & \multicolumn{2}{|c|}{21.6} \\
\hline \multicolumn{4}{|l|}{ Education level } \\
\hline Illiterate & 49 & \multicolumn{2}{|c|}{7.9} \\
\hline Literate & 59 & \multicolumn{2}{|c|}{9.5} \\
\hline Elementary school & 289 & \multicolumn{2}{|c|}{46.6} \\
\hline High school & 133 & \multicolumn{2}{|c|}{21.5} \\
\hline Associate /Undergraduate Degree & 90 & \multicolumn{2}{|c|}{14.5} \\
\hline \multicolumn{4}{|l|}{ Duration of diabetes } \\
\hline Less than 1 year & 64 & \multicolumn{2}{|c|}{10.3} \\
\hline $1-5$ years & 158 & \multicolumn{2}{|c|}{25.5} \\
\hline 6-10 years & 197 & \multicolumn{2}{|c|}{31.8} \\
\hline 11-20 years & 144 & \multicolumn{2}{|c|}{23.2} \\
\hline 21 years and over & 57 & \multicolumn{2}{|c|}{9.2} \\
\hline \multicolumn{4}{|l|}{ Diabetes treatment type } \\
\hline Diet & 41 & \multicolumn{2}{|c|}{6.6} \\
\hline OAD & 265 & \multicolumn{2}{|c|}{42.7} \\
\hline Insulin & 212 & \multicolumn{2}{|c|}{34.2} \\
\hline OAD and Insulin & 75 & \multicolumn{2}{|c|}{12.1} \\
\hline Alternative Treatments & 3 & \multicolumn{2}{|c|}{0.5} \\
\hline \multicolumn{4}{|l|}{ Body Mass Index } \\
\hline No treatment & 24 & \multicolumn{2}{|c|}{3.9} \\
\hline Underweight & 3 & & \\
\hline Normal weight & 106 & & \\
\hline Overweight & 511 & & \\
\hline Total & 620 & & \\
\hline & Median & Per & tiles \\
\hline The DHPSC Sub-Factors & & $\begin{array}{c}25 . \\
\text { percentile }\end{array}$ & $\begin{array}{c}75 . \\
\text { percentile }\end{array}$ \\
\hline Interpersonal Relationships & 29.00 & 25.25 & 33.00 \\
\hline Personal Health Responsibility & 19.00 & 15.00 & 21.75 \\
\hline Diet & 10.00 & 7.00 & 12.00 \\
\hline Exercise & 6.00 & 3.00 & 9.00 \\
\hline Foot Care & 7.00 & 5.00 & 9.00 \\
\hline Blood glucose self-monitoring & 17.00 & 13.00 & 21.00 \\
\hline Adherence to the Recommended Regime & 10.00 & 8.00 & 10.00 \\
\hline Total Scale Score & 96.00 & 84.00 & 109.00 \\
\hline
\end{tabular}

OAD: Oral Antidiabetic; $\quad$ DHPSC: Diabetes Health Promotion Self-Care Scale

\section{Reliability analysis}

Cronbach's $\alpha$ inner consistence coefficient technique is performed to examine the reliability of Likert-type scales. The Cronbach's $\alpha$ coefficient was determined for DHPSC. The item-total correlation coefficients were explored for the relationship 
between the scores in the DHPSC test items and the total score of the test. In this study, Cronbach that evaluates the inner consistency value of the scale was found to be $\alpha=0.922$. It was determined that the scale was sufficient to protect and enhance the health of individuals with DM, to evaluate personal care behaviors comprehensively, and the inner consistence of the scale was ensured.

\section{Validity analysis}

Exploratory Factor Analysis (EFA) was applied to test the validity of the DHPSC. As a result of the EFA, a structure explaining
$72.66 \%$ of the total variance of the data structure used in the scale consisting of seven factors and 27 items emerged. The KaiserMeyer-Olkin index was determined to be 0.89 , supporting the suitability of the data for factor analysis. Bartlett's sphericity test was found to be significant $(\chi 2=10851.575$; $\mathrm{p}<0.001)$. The principal components method and the Varimax factor rotation method were utilized to determine the factors and the appropriate factors, respectively. It was seen that the scale has 7 sub-factors to show the DHPSC in patients. The rotated factor loads matrix is presented in Table 3 .

Table 3. Factor Matrix Loads According to the Varimax Rotation Method (AFA)

\begin{tabular}{|c|c|c|c|c|c|c|c|}
\hline Items & 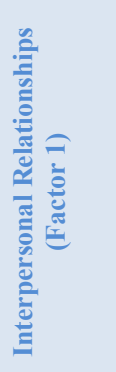 & 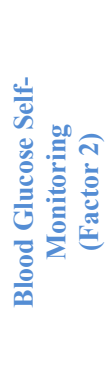 & 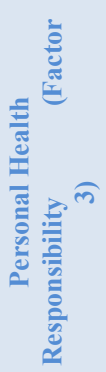 & 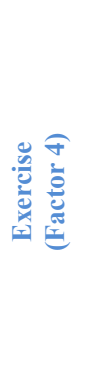 & 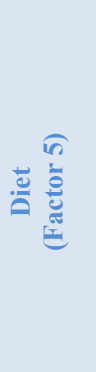 & 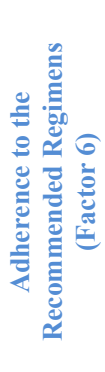 & 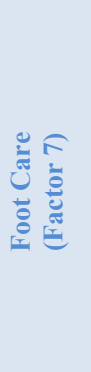 \\
\hline Item 1 & 0.727 & & & & & & \\
\hline Item 2 & 0.787 & & & & & & \\
\hline Item 3 & 0.837 & & & & & & \\
\hline Item 4 & 0.835 & & & & & & \\
\hline Item 5 & 0.793 & & & & & & \\
\hline Item 6 & 0.757 & & & & & & \\
\hline Item 7 & 0.638 & & & & & & \\
\hline Item 21 & & 0.821 & & & & & \\
\hline Item 22 & & 0.824 & & & & & \\
\hline Item 23 & & 0.780 & & & & & \\
\hline Item 24 & & 0.823 & & & & & \\
\hline Item 25 & & 0.637 & & & & & \\
\hline Item 8 & & & 0.796 & & & & \\
\hline Item 9 & & & 0.808 & & & & \\
\hline Item 10 & & & 0.773 & & & & \\
\hline Item 11 & & & 0.420 & & & & \\
\hline Item 12 & & & 0.574 & & & & \\
\hline Item 16 & & & & 0.854 & & & \\
\hline Item 17 & & & & 0.912 & & & \\
\hline Item 18 & & & & 0.900 & & & \\
\hline Item 13 & & & & & 0.820 & & \\
\hline Item 14 & & & & & 0.844 & & \\
\hline Item 15 & & & & & 0.622 & & \\
\hline Item 26 & & & & & & 0.871 & \\
\hline Item 27 & & & & & & 0.881 & \\
\hline Item 19 & & & & & & & 0.809 \\
\hline Item 20 & & & & & & & 0.781 \\
\hline $\begin{array}{l}\text { xploratory } \\
\text { centage }(\%)\end{array}$ & 33.75 & 12.23 & 8.47 & 5.42 & 4.95 & 4.06 & 3.78 \\
\hline
\end{tabular}

EFA: Exploratory Factor Analysis 


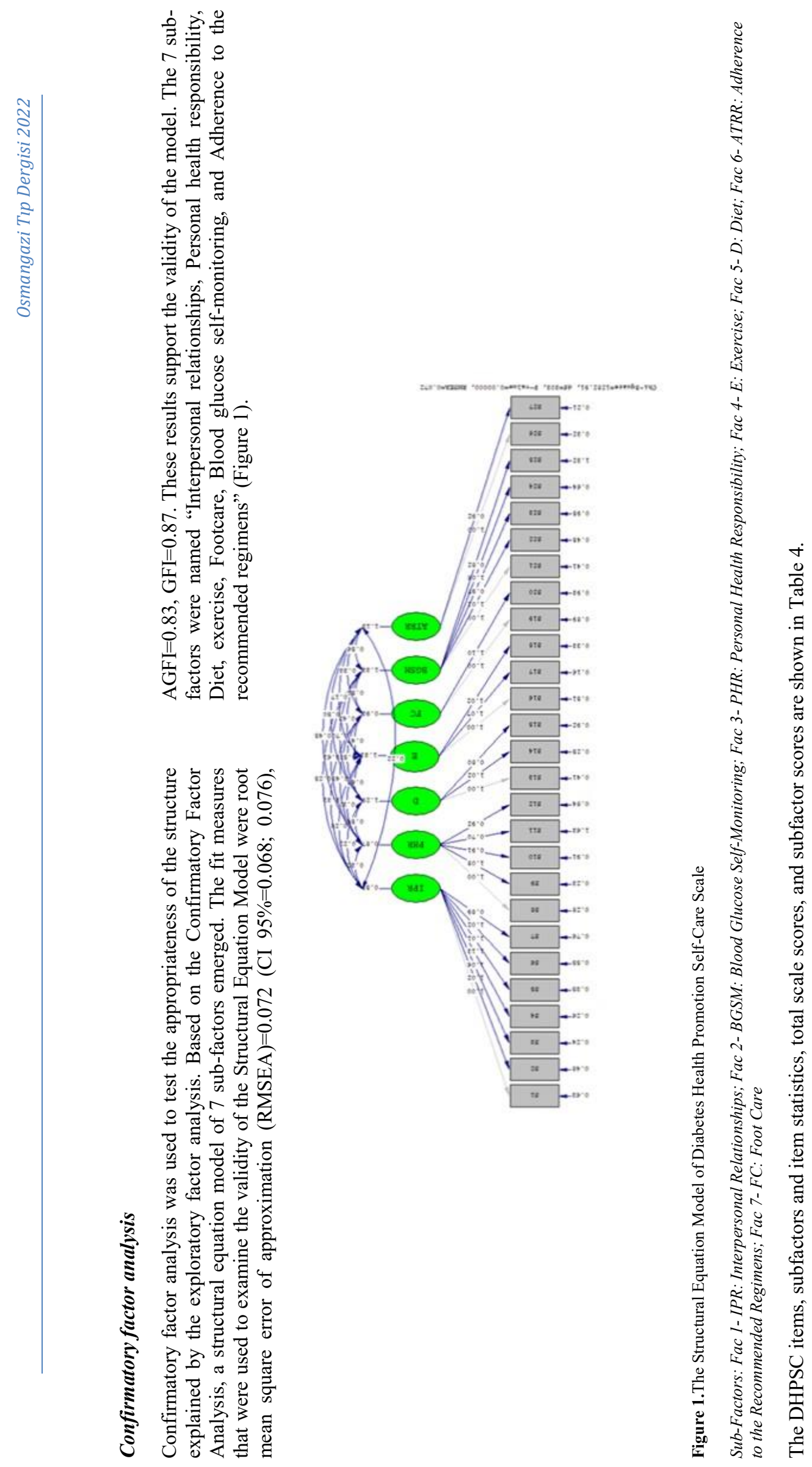




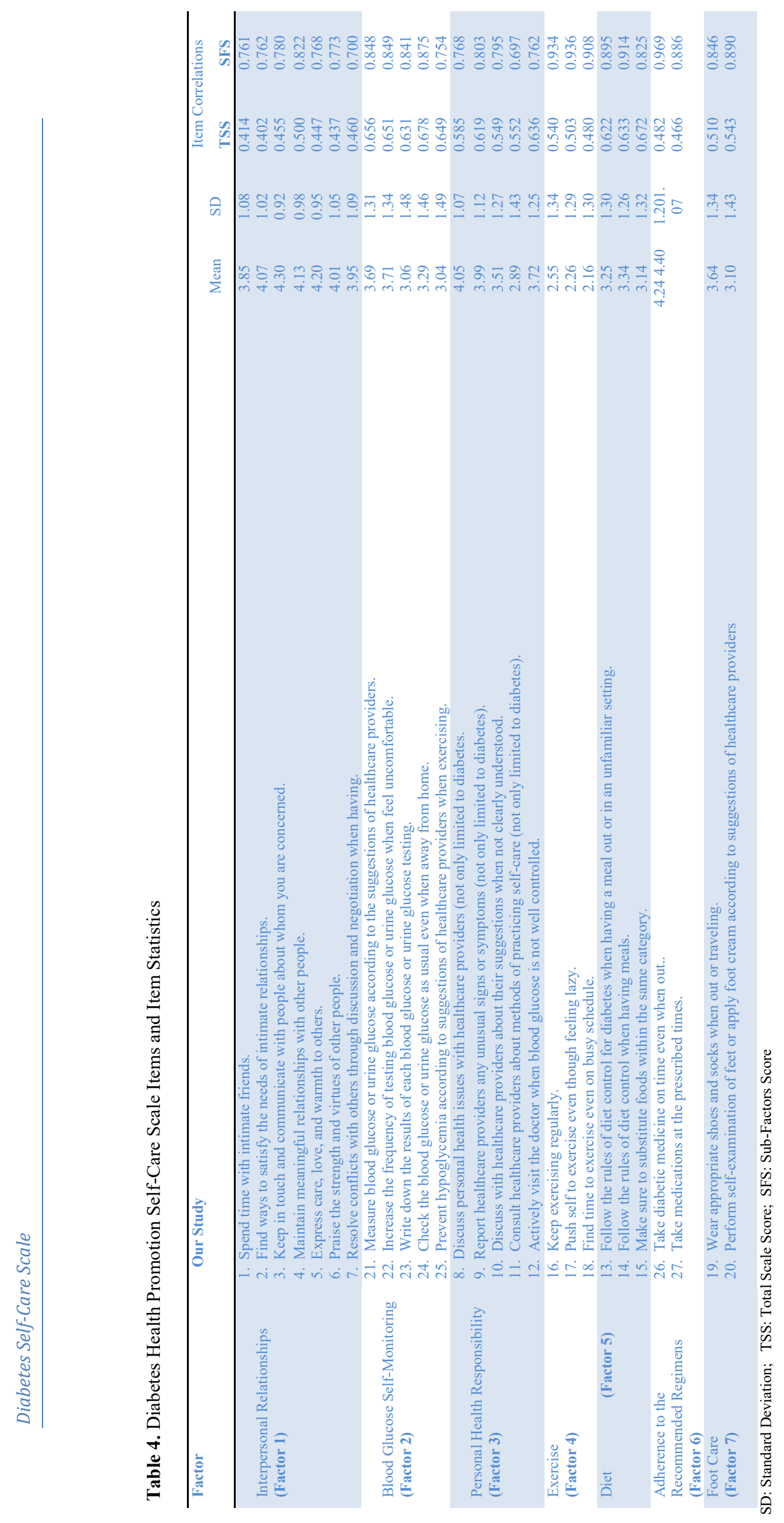




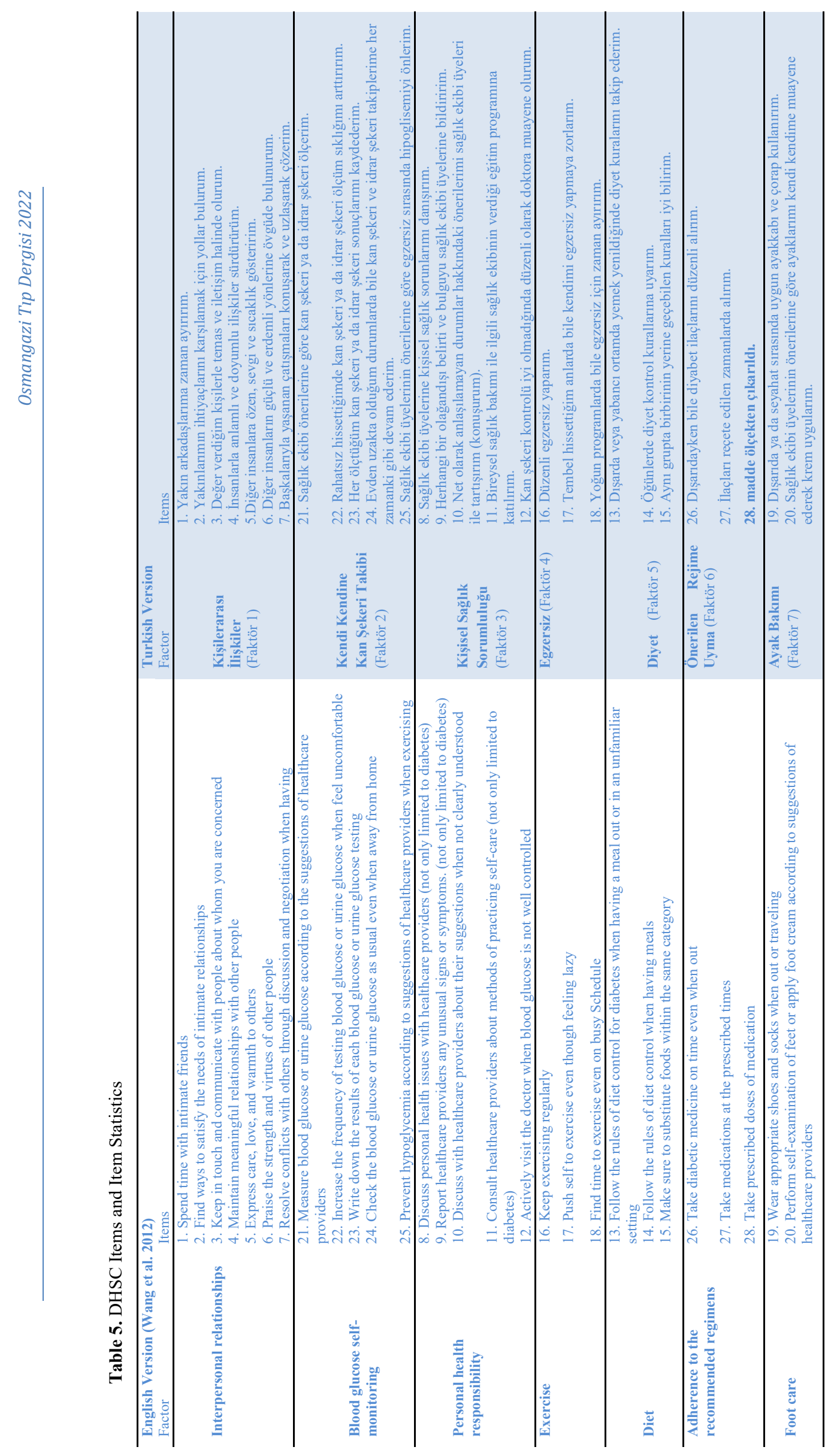


The relationship between the DHPSC subfactors was determined using the Pearson correlation factor, and a significant relationship between each of the subfactors was observed in table $1(\mathrm{p}<.001)$. Table 1 also gives Cronbach $\alpha$ values demonstrating the contribution of subfactors to the scale. The contribution of the "Diet" sub-factor to the scale was found lower compared to other subfactors.

Original scale subfactors and Turkish version scale subfactors and items are given in Table 5.

\section{Discussion and Conclusion}

The DHPSC can significantly contribute to the assessment of certain aspects of patients' health promotion self-care behaviors by nurses and to make particular interference for individuals with DM after this assessment (19). The scale includes 7 critical issues that individuals with diabetes should pay attention to in their self-care. It consists of 7 independent parts, and each question is short, concise, and understandable, so the implementation period is short. Individuals with diabetes can apply the scale themselves without the help of any healthcare staff.

DHPSC scale consists of 7 parts as diet (three items), exercise (three items), blood glucose self-monitoring (five items), adherence to recommended regimens (three items), foot care (two items), interpersonal relationships (seven items), and personal health responsibility (five items).

In this study, the Turkish validity and reliability of the scale improved by Wang et al. (19) were tested to determine the healthpromoting self-care behavior of individuals with diabetes to present the Turkish literature a scale that can reveal accurate, consistent, and valid data. The data were collected from the sample of individuals with Type $2 \mathrm{DM}$ admitted to a public university hospital, and analysis studies were conducted on these data. The conclusions provided a significant idea about the diabetes self-management of patients. However, the lack of a sufficient few studies in which the validity and reliability of DHPSC were conducted to evaluate the health promotion self-care behaviors of individuals with Type 2 DM made it challenging to discuss the findings in detail.

This part handles the evidence of the study performed to test the reliability and validity of the "DHPSC" under the following headings:

\section{Discussion of the results on the reliability of the DHPSC}

The reliability of the DHPSC was found as Cronbach $\alpha=0.922$, which shows that this is a highly reliable scale to measure diabetes selfmanagement in individuals with Type $2 \mathrm{DM}$. While the Cronbach $\alpha$ value was found to be 0.88 in the study of Wang et al. (19), it was determined as 0.71 in a cross-sectional study $(n=304)$ in which Nie et al. (23) examining disease perception, risk perception, and health promotion self-care behaviors in Chinese patients with type $2 \mathrm{DM}$. Consistent with the literature studies, the reliability of this study was determined to be high. The reliability values of the sub-factors in the study of Wang et al. (19) and in this study were determined as follows respectively; the sub-factor of "Interpersonal Relationships" was $\alpha=0.90$, in this study $\alpha=0.896$; the sub-factor of "Blood Glucose Self-Monitoring" was $\alpha=0.84$, in this study $\alpha=0.831$; the sub-factor of "Personal Health Responsibility" $\alpha=0.80$, in this study $\alpha$ $=0.856$; the sub-factor of "Exercise" $\alpha=0.94$, in this study $\alpha=0.925$; the sub-factor of "Diet" $\alpha=0.90$, in this study $\alpha=0.689$; the subfactor of "Adherence to the Recommended Regime" was $\alpha=0.78$, in this study, $\alpha=0.893$; the sub-factor of "Foot Care" could not be determined among the individuals study, $\alpha=0.886$ in this study. In the study of Nie et al. (23), the alpha reliability coefficient ranged between 0.64 and 0.93 .In the study conducted by Wang et al. (19), the reliability of the "Foot Care" sub-factor could not be determined, the "Adherence to the Recommended Regime" factor was determined to be $\alpha=0.78$, and in our study the "Diet" sub-factor was $\alpha=0.689$.It is emphasized that patients with diabetes who can follow dietary self-care advice generally have better glycemic control, resulting in less diabetic complications. However, it is emphasized that it is challenging to motivate 
patients to achieve self-care behaviors with diet and requires ongoing efforts between patients and a multidisciplinary team (24). Relevant studies noted that the compliance of individuals with diabetes to dietary recommendations is not at the desired level $(24,25)$. In parallel to the literature $(24,25)$, it was determined in this study that $6.6 \%$ of individuals with diabetes were on a diet, and the median of "diet" mean score was lower than the other sub-factors. In our study, the findings related to diet in Table 2 are thought to have an effect on the low alpha reliability coefficient obtained in the "diet" sub-factor. However, since the "diet" sub-factor is a significant therapeutic approach in promoting health in individuals with diabetes, it was not excluded from the scale despite its low alpha reliability coefficient. It can be said that obtaining low alpha reliability coefficients for different sub-factors in the study of Wang et al. (19) and our study is due to the treatment approaches used by patients in the treatment of diabetes, the cultural differences of countries, and the number of different samples included in the studies.

\section{Discussion of the results on the validity of the DHPSC}

For the structural validity of the scale, EFA analysis was performed for the data belonging to the patient group. As a outcome of the analysis, 7 sub-factors emerged, which was consistent with the original scale. The "Adherence to the Recommended Regime" sub-factor in the original scale consists of 3 items (items 26, 27, and 28). However, the 28th item "Take prescribed doses of medication" was removed in our study because its contribution to the scale was very low. Oral antidiabetic drug (OAD) treatment is the main treatment method used especially in the early phases of diabetes management in individuals with type 2 diabetes whose insulin secretion ability has not yet been exhausted $(26,27)$. The effectiveness of the treatment depends on the individual's adherence to drug treatment. Adherence to drug treatment includes the patient's adherence to medical recommendations, believing and accepting the treatment, taking responsibility for his/her own treatment, participating in treatment- related training if necessary, performing his/her treatment properly and on time, and attending regular health checks. However, the literature on oral drug use in individuals with diabetes has reported that patients confuse their medications, take medication at the wrong dose or at the wrong time, stop using the medication on their own, and make mistakes such as using non-prescription medication $(28,29)$. This study determined that $42.7 \%$ of individuals with diabetes used OAD, and the average score of "Adherence to the Recommended Regime" was lower than other sub-factors (Table 2). The reason why item 28 was excluded from the scale in our study was the inability of diabetic individuals to comply with the "Take prescribed doses of medication" item due to their education levels or to perform them adequately. However, it was determined that the items belonging to other sub-factors were collected under the same factors as the items designed in the original scale (Table 5).

As a result of the EFA applied to determine the structural validity of the DHPSC, it was seen that the scale was in the form of a structure that explained $72.66 \%$ of the total variance. In EFA, the scale was divided into 7 sub-factors named "Interpersonal Relationships", "Blood Glucose Selfmonitoring", "Personal Health Responsibility", "Exercise", "Diet", "Adherence to the Recommended Regime" and "Foot Care". The explanatoriness of the variances of the sub-factors were $33.75 \%$, $12.23 \%, 8.47 \%, 5.42 \%, 4.95 \%, 4.06 \%$, and $3.78 \%$, in turn. All the questions contribute significantly to the whole scale. This result shows that the data structure is suitable for factor analysis. Similar to our study, in the study of Wang et al. (19), the scale was also divided into 7 sub-factors. The authors named the sub-factors "Interpersonal Relationships", "Blood Glucose Self-monitoring", "Personal Health Responsibility", "Exercise", "Diet", "Adherence to the Recommended Regime" and "Foot Care". The explanatoriness of the variances of the sub-factors were found as $21.30 \%, 16.81 \%, 27.04 \%, 38.44 \%, 39.69 \%$, $9.30 \%$, and $68.89 \%$, respectively. In the study conducted by Wang et al. (19) on Taiwanese patients $(n=489)$, it was determined that the 
"Foot Care" subfactor made the highest contribution to the scale, and in our study, it was the "Interpersonal Relations" The results show that Taiwanese patients with Type 2 diabetes regarded "foot care" behavior as essential in health promotion self-care behavior, and our study "interpersonal relationships" behavior. The difference between Wang et al.'s (19) study and our study on the item that made the highest addition to the scale may have resulted from the health system of countries and the cultural differences of the patients and countries included in the sample. In a relevant study, health promotion behavior is stated to be affected by culture (30), so DHPSC should be evaluated for use in different countries.

Structural Equation Modeling is an analysis that explores the addition of sub-factors developed by confirmatory factor analysis to the model and verifies the findings $(31,32)$. When the validity of the model confirmed for the DHPSC was tested with compliance criteria, it was determined that the factor structure that emerged in the applied structural equation model was compatible according to the results of the factor analysis. Fit measures of the DHPSC's Structural Equation Model were found as RMSEA $=0.072$ (CI $95 \%=0.068 ; \quad 0.076) \quad$ AGFI $=0.83 \quad$ and $\mathrm{GFI}=0.87$, and the results reveal that the model is a scale that can be utilized to determine self-care management in patients with Type 2 diabetes.

\section{Study Limitations}

The study evaluates only the data of patients admitted to a university hospital diabetes outpatient clinic. It does not include the health-promoting self-care habits of patients who apply to private centers.

\section{Conclusion}

It is concluded in the study that DHPSC was a valid and reliable scale to be applied to Turkish society. Nurses can apply the DHPSC to evaluate the health promotion self-care behaviors of patients with Type 2 diabetes, and they can provide effective interventions to promote the habits of patients with Type 2 diabetes.
However, for the validity and reliability of the scale, further comprehensive studies on different sample groups (such as state, university, private hospitals, private diabetes centers), in different countries and cultures are required.

\section{Declarations}

Ethics approval and consent to participate: For the scale to be used in this study permission was obtained from the author "Ruey-Hsia Wang" and necessary revisions were made according to the suggestions. Ethics committee approval was procued from the Kocaeli University Non-Interventional Clinical Research Ethics Committee on 02.05.2021 with the decision number GOKAEK-2021/9.14, 2021/164. It was conducted between May and July 2021 after obtaining the permissions from Kocaeli University Research and Training Hospital, where the research was conducted. All the participants have been reported permission previous to their involvement to the study.

\section{Acknowledgments}

Thanks to Ruey-Hsia Wang for giving permission to use DHPSC in this study. 


\section{REFERENCES}

1. Ogurtsova K, da Rocha Fernandes JD, Huang Y, Linnenkamp U, Guariguata L, Cho NH, et al. IDF Diabetes Atlas: Global estimates for the prevalence of diabetes for 2015 and 2040 . Diabetes Res Clin Pract. 2017;128:40-50.

2. American Diabetes Association. Classification and diagnosis of diabetes: Standards of medical care in Diabetes-2018. Diabetes Care. 2018;41:13-27.

3. Satman I, Yilmaz T, Sengül A, Salman S, Salman F, Uygur S, et al. Population-based study of diabetes and risk characteristics in Turkey: Results of the Turkish Diabetes Epidemiology Study (TURDEP). Diabetes Care 2002;25:1551-6.

4. Toljamo M, Hentinen M. Adherence to self-care and glycaemic control among people with insulindependent diabetes mellitus. $J$ Adv Nurs. 2001;34:780-6.

5. Young-Hyman D, De Groot M, Hill-Briggs F, Gonzalez JS, Hood K, Peyrot M. Psychosocial care for people with diabetes: A position statement of the American Diabetes Association. Diabetes Care. 2016;39:2126-40.

6. Teixeira CR de S, Becker TAC, Citro R, Zanetti ML, Landim CAP. Validação de intervenções de enfermagem em pessoas com diabetes mellitus. Rev da Esc Enferm da USP. 2011;45:173-9.

7. Luo X, Liu T, Yuan X, Ge S, Yang J, Li C, et al. Factors Influencing Self-Management in Chinese Adults with Type 2 Diabetes: A Systematic Review and Meta-Analysis. Int $J$ Environ Res Public Health. 2015;12:11304-27.

8. Orem DE. A concept of self-care for the rehabilitation client. Rehabil Nurs. 1985;10:33-6.

9. Hartweg DL. Health promotion self-care within Orem's general theory of nursing. J Adv Nurs. 1990; 15:35-41.

10. Furler J, Walker C, Blackberry I, Dunning T, Sulaiman N, Dunbar J, et al. The emotional context of self-management in chronic illness: A qualitative study of the role of health professional support in the self-management of type 2 diabetes. BMC Health Serv Res. 2008;8:1-9.

11. Behrang K, Hamid T, Milad B, Asma T. The Effect of Self-Care on Glycated Hemoglobin and Fasting Blood Sugar Levels on Adolescents with Diabetes. Journal Of Comprehensive Pediatrics; 2018;9:e62661

12. Trompette J, Kivits J, Minary L, Alla F. Dimensions of the Complexity of Health Interventions: What Are We Talking about? A Review. Int $J$ Environ Res Public Health. 2020;17:3069.

13. Mendoza-Ruvalcaba NM, Arias-Merino ED. "I am active": Effects of a program to promote active aging. Clin Interv Aging. 2015;10:829-37.

14. Eigenmann CA, Colagiuri R, Skinner TC, Trevena L. Are current psychometric tools suitable for measuring outcomes of diabetes education? Diabet Med. 2009;26:425-36.

15. Toobert DJ, Hampson SE, Glasgow RE. The summary of diabetes self-care activities measure:
Results from 7 studies and a revised scale. Diabetes Care. 2000;23:943-50.

16. Khagram L, Martin CR, Davies MJ, Speight J. Psychometric validation of the Self-Care Inventory-Revised (SCI-R) in UK adults with type 2 diabetes using data from the AT.LANTUS Follow-on study. Health Qual Life Outcomes. 2021;11:1-9.

17. Usta Yeşilbalkan Ö. Tip 2 Diyabetli Hastaların Kendi Kendine Bakımlarındaki Öz Yeterlilikleri Öz Bakım Güçleri ve Bunları Etkileyen Faktörlerin İncelenmesi. 2004.

18. Lee J, Lee E, Chae D. Self-efficacy instruments for type 2 diabetes self-care: A systematic review of measurement properties. $J$ Adv Nurs. 2020;76:2046-59.

19. Wang R-H, Lin L-Y, Cheng C-P, Hsu M-T, Kao C-C. The Psychometric Testing of the Diabetes Health Promotion Self-Care Scale. J Nurs Res. 2012;20:122-30.

20. Kuan G, Kueh YC, Abdullah N, Tai ELM. Psychometric properties of the health-promoting lifestyle profile II: cross-cultural validation of the Malay language version. BMC Public Health. 2019;19:751.

21. Wong AKY, Stewart AGO, Furler JS. Development and validation of the Diabetes Management Orientation Scale (DMOS): Assessing culturally related approaches to diabetes self-management. Diabetes Res Clin Pract. 2009;86:24-30.

22. Sousa VD, Rojjanasrirat W. Translation, adaptation and validation of instruments or scales for use in cross-cultural health care research: A clear and user-friendly guideline. Journal of Evaluation in Clinical Practice. 2011;17:268-74.

23. Nie R, Han Y, Xu J, Huang Q, Mao J. Illness perception, risk perception and health promotion self-care behaviors among Chinese patient with type 2 diabetes: A cross-sectional survey. Appl Nurs Res. 2018;39:89-96.

24. Thewjitcharoen Y, Chotwanvirat P, Jantawan A, Siwasaranond N, Saetung S, Nimitphong H, et al. Evaluation of dietary intakes and nutritional knowledge in Thai patients with type 2 diabetes mellitus. J Diabetes Res. 2018;2018.

25. Tan SL, Juliana S, Sakinah H. Dietary Compliance and its Association with Glycemic Control among Poorly Controlled Type 2 Diabetic Outpatients in Hospital Universiti Sains Malaysia. Mal J Nutr. 2011;17.

26. American Diabetes Association. Standards of Medical Care in Diabetes-2016 Abridged for Primary Care Providers. Clin Diabetes. 2016;34:3-21.

27. Türkiye Endokrinoloji ve Metabolizma Derneği, Diabetes Mellitus Çalışma ve Eğitim Grubu. Diabetes Mellitus ve Komplikasyonlarinin Tani, Tedavi ve İzlem Kilavuzu. 2020.

28. Adisa R, Alutundu MB, Fakeye TO. Factors contributing to nonadherence to oral 
hypoglycemic medications among ambulatory type 2 diabetes patients in Southwestern Nigeria. Pharm Pract (Granada). 2009;7:163-9.

29. Sayin Kasar K, Kizilci S. Oral Antidiyabetik İlaç Kullanım Hataları ve Etkileyen Faktörler. Gümüşhane Üniversitesi Sağlık Bilimleri Dergisi. 2017;6:128-37

30. Tripp-Reimer T, Choi E, Kelley LS, Enslein JC. Cultural Barriers to Care: Inverting the Problem. Diabetes Spectr. 2001;14:13-22.

31. Albright JJ, Park HM. Confirmatory Factor Analysis Using Amos, LISREL, Mplus, and SAS/STAT CALIS. Working Paper. The University Information Technology Services (UITS) Center for Statistical and Mathematical Computing, Indiana University. 2006.

32. Baydemir C, Özdamar K, Ünalır A. Validity of the Turkish version of the European Heart Failure Self-Care Behavior Scale Avrupa Kalp Yetersizliği Öz-Bakım Davranış Ölçeği'nin Türkçe'ye uyarlanması. Anadolu Kardiyol Derg. 2013;13:573-82. 